\title{
SCORPIONS ARE A FOOD ITEM OF AMERICAN BLACK BEARS IN SONORA, MEXICO
}

\author{
Carlos A. López-González ${ }^{1}$, Robert W. Jones ${ }^{1,2}$, Carmen Silva-Hurtadoㄹ, and Ivan A. Sáyago-Vázquez ${ }^{1}$
}

ABSTRACT.-The remains of the scorpion Diplocentrus peloncillensis Francke were found in 7 scats of black bears (Ursus americanus) collected in the Sierra de San Luis, Sonora, Mexico. The collection data and previously reported black bear population estimates for the study area suggested that, although scorpions are not a large part of black bear diets in Sonora, feeding on scorpions is not restricted to a single individual or family unit and is apparently a relatively common behavior in the population. Also, the discovery of D. peloncillensis in Sonora represents a new country record.

Key words: American black bear, Ursus americanus, diet, scorpion, Diplocentrus peloncillensis.

Resumen.-Se encontraron restos del escorpión, Diplocentrus peloncillensis Francke, en siete heces de oso negro (Ursus americanus) colectados en la Sierra de San Luis, Sonora, Mexico. Los datos de colección y estimaciones poblaciones previas de osos negros para el área de estudio sugieren que, aunque los escorpiones no son una parte importante en la dieta del oso negro en Sonora, la alimentación de escorpiones no estuvo restringida a un solo individuo ni a una familia y es un comportamiento relativamente común dentro de la población. Aparte, el descubrimiento de la especie $D$. peloncillensis en Sonora representa un nuevo registro para México.

American black bears (Ursus americanus) are omnivores (Maehr and Brady 1984, Leopold 1985, Hellgren 1993, Stubblefield 1993, Beecham and Rohlman 1994, Doan-Crider 1995, SEMARNAP 1999), and the diets of individuals vary depending on the geographic location and habitat type where they are found (Beecham and Rohlman 1994, Lariviere 2001). Black bears in forested montane "islands" surrounded by desert landscapes exhibit feeding habits (Sierra Corona et al. 2005, Rodriguez Martinez et al. 2008) different from black bears at northern latitudes (Maehr and Brady 1984, Hellgren 1993, Stubblefield 1993). We report, for the first time, evidence that scorpions are part of the diet of black bears in Sonora, Mexico.

A total of 180 bear scats were collected from the "El Pinito" Ranch, located in the Sierra de San Luis, Sonora, Mexico (northwestern corner: $31.20^{\circ} \mathrm{N}, 109.94^{\circ} \mathrm{W}$; southeastern corner: $31.12^{\circ} \mathrm{N}, 108.82^{\circ} \mathrm{W}$ ) (Fig. 1), during April-November 2002. Through separation and analysis, remains of scorpions were found in 7 scats. These remains allowed us to identify the consumed species as Diplocentrus peloncillensis Francke. The fragments are stored as vouchers in the Zoological Collection of the
Facultad de Ciencias Naturales, Universidad Autónoma de Querétaro, Querétaro, México.

The scats that contained the remains of $D$. peloncillensis were collected at 7 different localities during 5 different months and in 2 different forest habitats. The specimens were almost equally distributed between the wet and dry seasons (Fig. 1). Four of the scats were found within the same general area in open low forests but during 3 different months. The other 3 scats were found in pine-oak or open low forests more than $2 \mathrm{~km}$ from other collections (Fig. 1). It is possible that all scats were from the same individual or family group. However, at least 16 individuals were estimated to be present within the ranch (Sierra Corona et al. 2005), and because black bears have overlapping foraging ranges (LeCount 1982, Lariviere et al. 1994), the temporal and spatial separation of scats suggests that feeding on scorpions may have been a behavior of several individuals.

The presence of $D$. peloncillensis in bear scats from Sonora also represents a new country record for this species. Although the collection method is unusual, the presence of $D$. peloncillensis in Sonora, Mexico, is not particularly surprising given that the species is

\footnotetext{
${ }^{1}$ Facultad de Ciencias Naturales, Universidad Autónoma de Querétaro, Avenida de las Ciencias, s/n, Juriquilla, C.P. 76230, Santiago de Querétaro, Querétaro, México.

${ }^{2}$ Corresponding author. E-mail: rjones@uaq.mx
} 


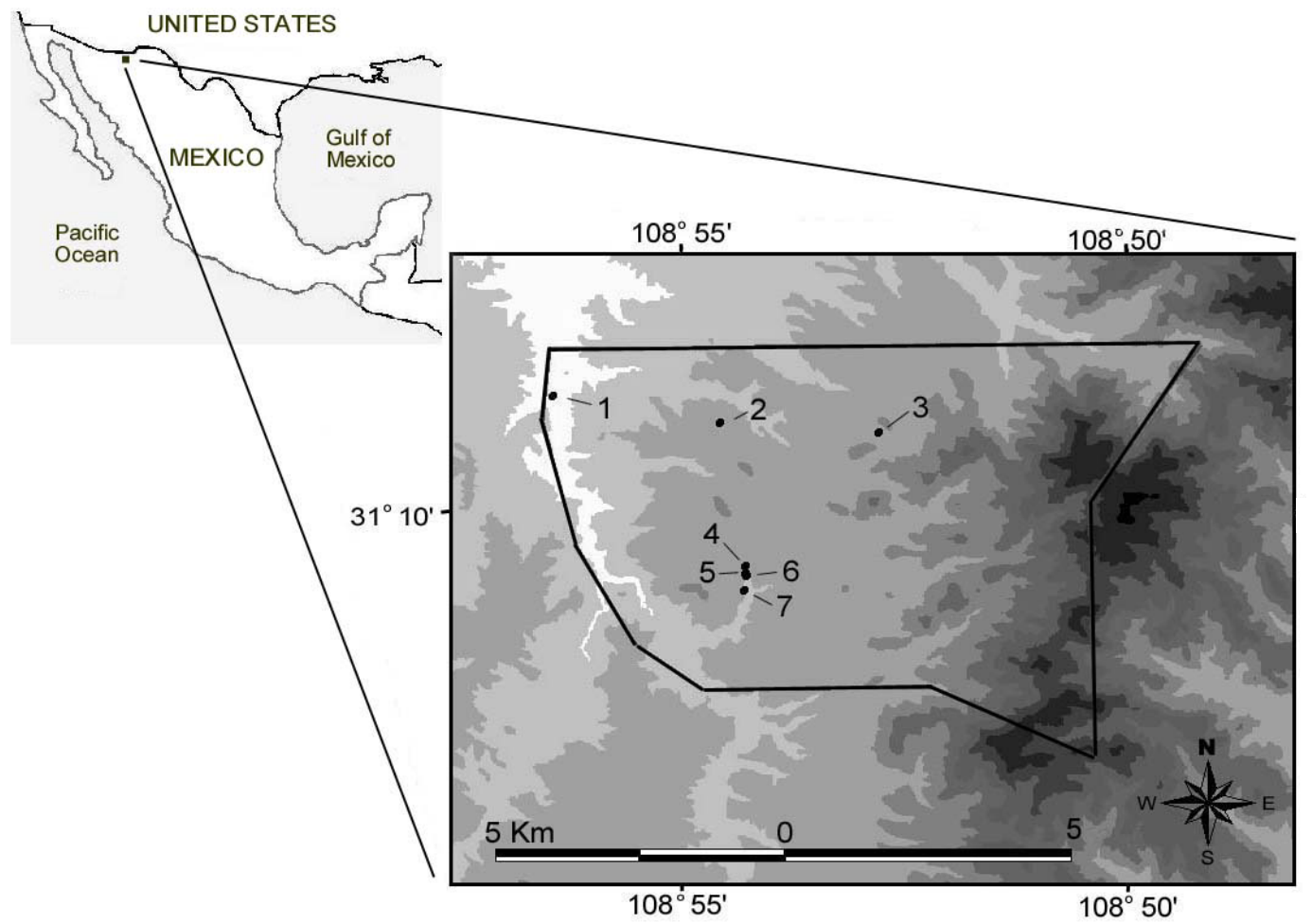

Fig. 1. Study site at "El Pinito" Ranch (outlined) in Sonora, Mexico, showing locations of black bear scats containing remains of scorpions. Altitudinal contour lines are at 90-m intervals from $1260 \mathrm{~m}$ (lightest gray) to $2515 \mathrm{~m}$ (darkest gray). Numbers refer to individual scat collections containing remains of the scorpion species Diplocentrus peloncillensis. Collection data are as follows: (1) July 2002, wet season, pine-oak forest; (2) October 2002, dry season, pine-oak forest; (3) September 2002, wet season, pine-oak forest; (4) August 2002, wet season, open low forest; (5) August 2002, wet season, open low forest; (6) October 2002, dry season, open low forest; (7) May 2002, dry season, pine-oak forest.

reported from the neighboring states of New Mexico and Arizona in the United States. Other species of Diplocentrus are reported only from the United States but also probably exist in adjacent Mexican states (Francke 1975).

The consumption of D. peloncillensis apparently does not constitute a large proportion of the diet in this black bear population $(3.8 \%$ frequency of occurrence in scats). Diplocentrus peloncillensis is known to have fossorial habits, living in deep burrows and ambushing prey at the entrance (Francke 1975). It is also known that the poison of $D$. peloncillensis is not lethal to vertebrates, and this may explain why bears are not averse to feeding on this species. Bears may feed on scorpions when individuals are encountered on the surface, and the frequency of encounters may be correlated with the sexual cycles of the scorpions. Males of $D$. peloncillensis seek females during the warm months and after rains (Oscar F.
Francke personal communication), at which time they travel on the soil surface (PonceSaaveda 2003), leaving them more exposed to predation. It is unknown whether bears eat scorpions only as the result of chance encounters when $D$. peloncillensis individuals are active aboveground or whether there is an actual functional response under certain conditions in which bears initiate active, directed searches for the species. More studies are necessary to determine the importance of scorpions in the diet of black bears and what factors lead to their consumption.

We thank Dr. Oscar F. Francke for species identification and for his valuable suggestions and contribution of pertinent literature. We also thank Dr. Javier P. Saavedra for reviewing early drafts of this manuscript. This is Publication No. 2 of the Cuerpo Academico de Ecologia y Diversidad Faunistica UAQ. 


\section{Literature Cited}

BeECham, J., AND J. Rohlman. 1994. A shadow in the forest: Idaho black bear. University of Idaho Press, Moscow, ID.

DoAn-Crider, D.L. 1995. Population characteristics and home range dynamics of a black bear population in northern Coahuila, México. Master's thesis, Texas A\&M University, College Station.

FrancKe, O.F. 1975. A new species of Diplocentrus from New Mexico and Arizona (Scorpionida, Diplocentridae). Journal of Arachnology 2:107-118.

Hellgren, E.C. 1993. Status, distribution, and summer food habits of the black bears in Big Bend National Park. Southwestern Naturalist 38:77-80.

LARIVIERE, S. 2001. Ursus americanus. Mammalian Species 647:1-11.

Lariviere, S., J. Hout, and C. Samson. 1994. Daily activity patterns of female black bears in a northern mixedforest environment. Journal of Mammalogy 75:613620 .

LECounT, A.L. 1982. Characteristics of a central Arizona black bear population. Journal of Wildlife Management 46:861-868.

LeOpold, A.S. 1985. Fauna Silvestre de México. Instituto Mexicano de Recursos Naturales Renovables. México, D.F.

Maenr, D.S., AND J.R. BRady. 1984. Food habits of Florida black bears. Journal of Wildlife Management 48:230 235.

Ponce-SaAveda, J. 2003. Ecología y distribución del género Centruroides Marx 1980 (Scorpiones: Buthi- dae), en la Depresión del Balsas en el estado de Michoacán. Tesis de Docotorado. Facultad de Ciencias Naturales, Universidad Autónoma de Querétaro, Querétaro, México.

Rodriguez Martinez, A., C.N. Moreno Arzate, E. R. Gonzalez Sierra, and C.A. López GonzÁlez. 2008. Spatial ecology and population structure of endangered black bears (Ursus americanus) in northwestern Mexico. Western Black Bear Workshop 9:819.

SEMARNAP. 1999. Proyecto para la conservación y manejo del oso negro (Ursus americanus) en México. Instituto Nacional de Ecología, México.

Sierra Corona, R., I.A. Sayazo VazQuez, M. Del C. Silva Hurtado, and C.A. López GonzÁlez. 2005. Black bear abundance, habitat use, and food habits in the Sierra San Luis, Sonora. Pages 444-448 in G.J. Gottfried, B.S. Gebow, L.G. Eskew, and C. Edminster, editors, Connecting mountain islands and desert seas: biodiversity and management of the Madrean Archipelago II. 2004 May 11-15; Tucson, AZ. Proceedings RMRS-P-36, USDA Forest Service, Rocky Mountain Research Station, Fort Collins, CO.

Stubblefield, C.H. 1993. Food habits of black bear in the San Gabriel Mountains of southern California. Southwestern Naturalist 38:290-293.

Received 10 April 2008 Accepted 10 July 2008 